\title{
SOME INEQUALITIES FOR RECIPROCALLY $(s, m)$-CONVEX IN THE SECOND SENSE FUNCTIONS AND APPLICATIONS TO SPECIAL MEANS
}

\author{
Mireya R. Bracamonte, Jesús Medina-Viloria and Miguel \\ VIVAS-CORTEZ
}

\begin{abstract}
We present the notion of reciprocally $(s, m)$-convex functions and present some examples and properties of them. We derive some inequalities for this new class of functions, specifically these inequalities are: Hermite-Hadamard and Fejér. In addition, we present some applications of our results to special media of positive real numbers.
\end{abstract}

Mathematics subject classification (2010): 26D15, 52A40, 26 A51.

Keywords and phrases: Harmonically convex functions, classics inequalities, special means.

\section{REFERENCES}

[1] BaZaraA, M. S. And ShetTy, C. M., Nonlinear Programming Theory and Algorithms, New York: John Wiley and Sons, 3rd ed, 2006.

[2] Hiriart-Urruty, J.-B. ANd Lemaréchal, C., Convex analysis and minimization algorithms I, Springer, 1996.

[3] Hiriart-Urruty, J.-B. And Lemaréchal, C., Convex analysis and minimization algorithms I, Springer-Verlag Berlin Heidelberg, 1996.

[4] Chen, F. And Wu, S., Fejér and Hermite-Hadamard Type Inequalities for Harmonically Convex Functions, Hindawi Publishing Corporation Journal of Applied Mathematics, 2014.

[5] İşCAN, İ., Hermite-Hadamard type inequalities for harmonically convex functions, Hacettepe Journal of Mathematics and Statistics Volume 43 (6), 2014, 935-942.

[6] İşCAN, I., Ostrowski type inequalities for harmonically s-convex functions, Konuralp Journal of Mathematics, Volume 3 No. 1, 2015, 63-74.

[7] Lara, T., Merentes, N., Quintero, R. and Rosales, E., On Strongly m-Convex Functions, Mathematica Aeterna, Vol. 5,no. 3, 2015, 521-535.

[8] Dwilewicz, R. J., A short history of Convexity, Differential Geometry - Dynamical Systems, Vol.11, 2009, 112-129.

[9] Dragomir, S. And Pearce, C., Selected Topics on Hermite-Hadamard Inequalities and Applications, RGMIA Monographs, Victoria University, 2002.

[10] S. Rivas And N. Merentes, El Desarrollo del Concepto de Función Convexa, Escuela Venezolana de Matemáticas. Caracas, Venezuela, 2013.

[11] Beckenbach, E. F., Convex functions, Bull. Amer. Math. Soc. 54, no. 5, 1948, 439-460.

[12] Azócar, A., Nikodem, K. And RoA, G., Fejer-type inequalities for strongly convex functions, Ann. Math. Silesianae 26, 2012, 43-54.

[13] Kikianty, E., S.S. Dragomir AND P. CERone, Sharp inequalities of Ostrowski type for convex functions defined on linear spaces and application, Computers and Mathematics with Applications 56, 2008, 2235-2246.

[14] Ghazanfari, A. G. And Dragomir, S. S., Hermite-Hadamard inequality for functions whose derivatives absolute values are preinvex, J. Inequal. Appl., 2012, 243.

[15] AzPeitia, A.G., Convex functions and the Hadamard inequality, Rev. Colombiana Math., 1994, $7-12$.

[16] OstrowsKI, A., Über die Absolutabweichung einer differentiebaren Funktion von ihrem Integralmittelwert, Comment. Math. Helv. 10, 1938, 226-227. 
[17] Kilbas, A., Srivastava, H.M. And Trujillo, J.J., Theory and Applications of Fractional Differential Equations, Elsevier B.V, Amsterdam, Netherlands, 2006.

[18] Hadamard, J., Étude sur les propriétés entières et en particulier d'une fonction considérée par Riemann, J. Math. Pures Appl., 58, 1893, 171-215.

[19] Hermite, CH., Sur deux limites d'une intégrale définie, Mathesis 3, 1883, 82.

[20] FEJÉR, L., Über die Fourierreihen II, Math. Naturwiss. Anz Ungar. Akad.Wiss., 1906, 369-390.

[21] DRAGOMIR, S. S., Inequalities of Hermite-Hadamard type for h-convex functions on linear spaces, Mathematica Moravica, 2015, 107-121.

[22] Dragomir, S. S. And Agarwal, R. P., Two inequalities for differentiable mappings and applications to special means of real numbers and to trapezoidal formula, Appl. Math. Lett., 11, No. 5, 1998, 91-95.

[23] Dragomir, S. S. And Pearce, C. E. M., Selected topics on Hermite-Hadamard inequalities and applications, RGMIA Monographs, Victoria University, 2000.

[24] POLYAK, B. T., Existence theorems and convergence of minimizing sequences in extremum problems with restrictions, Soviet Math. Dokl. 7, 1966, 72-75.

[25] Alomari, M. And Darus, M., Some Ostrowski type inequalities for convex functions with applications, RGMIA 13 (1), Article 3, 2010.

[26] Merentes, N. And Nikodem, K., Some remarks on strongly convex functions, Aequationes Math. 80, 2010, 193-199.

[27] Set, E., Ozdemir, M. E., Sarikaya, M. Z. and Akdemir, A. O., Ostrowski's Type Inequalities for Strongly-Conzvex Functions, Classical Analysis and ODEs (math.CA), 2012.

[28] DRAGOMIR, S. S., Inequalities of Jensen type for HA-convex functions, RGMIA Monographs, Victoria University, 2015.

[29] Baron, K., Matkowski, J. And Nikodem, K., A sandwich with convexity, Math. Pannica 5/1, 1994, 139-144.

[30] Roberts, A. W. And Varberg, D. E., Convex Functions, Academic Press, New York-London, 2006.

[31] Dragomir, S. S., Inequalities of Hemite-Hadamard type for HA-convex functions, RGMIA Monographs, Victoria University, 2015.

[32] Hua, J., XI, B. AND QI, F., Some new inequalities of Simpson type for strongly s-convex functions, Afrika Matematika, Volume 26, Issue 5, 2015, 741-752.

[33] Iscan, I., Hermite-Hadamard and Simpson-Like Type Inequalities for Differentiable Harmonically Convex Functions, Hindawi Publishing Corporation Journal of Mathematics Volume 2014, Article ID 346305, 10 pages, 2014.

[34] Hardy, A.W., Littlewood, J.E. And Polya, G., Inequalities, Cambridge Univ. Press., 1934.

[35] Pecaric, J. And Proschan, F., Convex functions, partial orderings, and statistical applications, Academic Press, Boston, 1992.

[36] Hudzik, H. And Maligranda, L., Some remarks on s-convex functions, Aequationes Math., 48, 1994, 100-111.

[37] Bougoffa, L., New inequalities about convex functions, Journal of Inequalities in Pure and Applied Mathematics, Volume 7, Issue 4, Article 148, 2006.

[38] Pinheiro, I. M. R., Jensen's Inequality in Detail and S-Convex Functions, Int. Journal of Math. Analysis, Vol. 3, no. 2, 2009, 95-98.

[39] Aslam Noor, M., Inayat Noor, K., Uzair Awan, M. and Costache, S., Some integral inequalities for harmonically h-convex functions, U.P.B. Sci. Bull., Series A, Vol. 77, Iss. 1, 2015, $5-16$.

[40] Baloch, I. A. AND Iscan, I., Some Ostrowski Type Inequalities For Harmonically $(s, m)$-Convex Functoins in Second Sense, International Journal of Analysis, Volume , Article ID 672675, 9 pages, 2015.

[41] IsCAN, I., Hermite-Hadamard type inequalities for harmonically $(\alpha, m)$-convex functions, Hacettepe Journal of Mathematics and Statistics, In press, 2015.

[42] Baloch, I. A., Iscan, I. AND Dragomir, S. S., Fejér type inequalities for Harmonically $(s, m)$ convex functions, RGMIA Res. Rep. Coll. 19, Art. 3, 2016.

[43] Eftekhari, N., Some remarks on $(s, m)$-convexity in the second sense, Journal of Mathematical Inequalities, Volume 8, Number 3, 2014, 489-495. 
[44] XI, B.-Y., QI, F. And ZHAng, T.-Y., Some inequalities of Hermite-Hadamard type for $m-$ harmonic-arithmetically convex functions, ScienceAsia 41, 2015, 357-361.

[45] Dragomir, S. S., Inequalities of Jensen Type for $h$-Convex Functions on Linear Spaces, Mathematica Moravica Vol. 19-1, 2015, 107-121.

[46] XI, B.-Y., WAng, S.-H. AND QI, F., Some inequalities for $(h, m)$-convex functions, Journal of Inequalities and Applications, 2014.

[47] XI, B.-Y., WAng, S.-H. AND QI, F., Some inequalities for $(h, m)$-convex functions, Journal of Inequalities and Applications, 2014.

[48] FARID, G. And REHMAn, A., Generalization of the Fejér-Hadamard's inequality for convex function on coordinates, Commun. Korean Math. Soc. 31, No. 1, 2016, 53-64.

[49] SET, A. AND IsCAN, I., Hermite-Hadamard type inequalities for harmonically convex functions on the co-ordinates, Preprint, 2014.

[50] Bracamonte, M., Ereú, J., Giménez, J. and Merentes N., On metric semigroups-valued functions of bounded Riesz- $\Phi$-variation in several variables, Bol. Soc. Mat. Mex., 2016, 1-21.

[51] Chistyakov, V. V., Functions of several variables of finite variation and superposition operators, Real Analysis Exchange 26th Summer Symposium, Lexington, VA, USA, 2002, 61-66.

[52] Chistyakov, V. V., A selection principle for mappings of bounded variation of several variables, Real Analysis Exchange 27th Summer Symposium, Opava, Czech Republic, 2003, 217-222.

[53] Noor, M. A., Noor, K. I. AND AwAN M. U., Integral inequalities for coordinated harmonically convex functions, Complex Var. Elliptic Equ. 60, 2015, 776-786.

[54] CHEN, F. AND WU, S., Hermite-Hadamard type inequalities for harmonically s-convex functions, Sci. World J. no. 7, Article ID 279158, 2014.

[55] Dragomir, S. S., Inequalities of Hermite-Hadamard type for h-convex functions on linear spaces, Proyecciones 34, no. 4, 2015, 323-341.

[56] DraGomir S. S., On the Hadamard's inequality for convex function on the coordinated in a rectangle from the plane, Taiwan. J. Math. 5(4), 2001, 775-778.

[57] Safdar, H., Rehman A., Malik, S. And Farid, G., On the Hadamard's inequalities for coordinate convex function, Proceedings of 1st ICAM Attock, Pakistan, 2015, 37-53.

[58] FARID, G. AND REHMAn A., Generalization of the Fejér-Hadamard's inequality for convex function on coordinates On the Hadamards inequalities for coordinate convex function, Commun. Korean Math. Soc. 31, 2016, 53-64.

[59] KlaRiČIĆ BAKUla, M. AND PEČARIĆ, J., On the Jensen's inequality for convex functions on the co-odinates in a rectangle from the plane, Taiwan. J. Math. Vol. 10, No. 5, 2006, 1271-1292.

[60] BANIĆ, S. AND KLARIČIĆ BAKULA, Jensen's inequality for functions supercuadratic on the coordinates, Journal of Mathematical Inequalities, Vol. 9, No. 4, 2015, 1365-1375.

[61] JENSEN J. L., On konvese functioner og uligheder imellem middelvaerdier, Nyt Tidsskr. Math. 16B, 1905, 49-69.

[62] Rockafellar, R.T., Monotone operator and the proximal point algorithm, SIAM J. Control Optim 14, 1976, 888-898.

[63] Jimenez, M. A., Garzón, G. R. and Lizana, A.R., Optimality Conditions in Vector Optimization, Bentham Science Publishers, Sharjah, 2010.

[64] Martini, H. And Swanepoel K. J., Generalized convexity notions and combinatorial geometry, Congr. Numer. 164, 2003, 65-93.

[65] Bracamonte, M., Giménez, J. And Medina, J., Hermite-Hadamard and Fejér type inequalities for strongly harmonically convex functions, MATUA. Vol. III, No. 2, 2016, 33-46.

[66] Bracamonte, M., Giménez, J., Medina, J. And Vivas, M., A sandwich theorem and stability result of Hyers-Ulam type for harmonically convex functions, Lecturas Matemáticas, Volumen 38 (1), 2017, 5-18.

[67] Bracamonte, M., Medina, J. And Vivas, M., On some Inequalities for Strongly Reciprocally Convex Functions, Extracta Mathematicae Vol. 33, Núm. 1, 2018, 109-126.

[68] Bracamonte, M., Giménez, J. and Medina, J., Ostrowski and Simpson Type Inequalities for Strongly Reciprocally Convex Functions, Applied Mathematics \& Information Sciences, II, No. 5, 2017, 1279-1285.

[69] Azócar, A., Bracamonte, M. And Medina, J., Some Inequalities of Jensen Type and Lazhar Type for the Class of Harmonically and Strongly Reciprocally Convex Functions, Applied Mathematics \& Information Sciences, II, No. 4, 2017, 1075-1080. 
[70] Bracamonte, M., Medina, J. And Merentes, N., Some inequalities for harmonically s-convex functions, Boletín de la Asociación Matemática Venezolana, Vol. XXIII, No. 2, 2016, 105-116.

[71] Medina, J. And Vivas, M., Hermite-Hadamard Type Inequalities for Harmonically Convex Functions on n-Coordinates, Appl. Math. Inf. Sci. Lett. 6, No. 2, 2018, 53-58.

[72] Medina, J. And Vivas, M., Jensen's Inequality for Convex Functions on N-Coordinates, Appl. Math. Inf. Sci. 12, No. 5, 2018, 1-5.

[73] Bracamonte, M., Giménez, J. And Vivas, M., Hermite-Hadamard-Fejér Type Inequalities for Strongly $(s, m)$-Convex Functions with Modulus $c$, in Second Sense, Appl. Math. Inf. Sci. 10, No. 6, 2016, 2045-2053.

[74] Vivas, M., Fejér Type Inequalities for $(s, m)$-Convex Functions in Second Sense, Appl. Math. Inf. Sci. 10, No. 5, 2016, 1689-1696. 